\title{
The Structure of a Sanskrit Drama
}

\author{
Ven. Dr. Lenagala Siriniwasa Thero
}

Head, Department of Sanskrit, Buddhist and Pali University of Sri Lanka - Homagama

Sanskrit drama is divided in to two types - Rūpakas (drama proper) and uparūpakas (forms of dance - drama). Both of them embody the three concepts which suggest the three most importance aspect of drama:

1) Nātya

2) Rūpa

3) Rūpaka [1]

The term Nātya represents the view point of the actor, because it is the actor who represents the states of the hero's personality on the stage. From the view point of the audience the Nātya is called Rūpa as it becomes an object of perceptual experience. It is termed as Rupaka from the view point of the dramatist, because it is he who through his art establishes the identification of the actors with the character in this real life. [2]

The Rūpakas are at first divided into two main types:

1) Full of different forms of action, complete in all their aspects (Pūrnavrutti Vrutyangā)

2) Having one or two forms of action incomplete in some of their aspects (Vruttinyūna) Nāțaka and Prakarana belong to the former type and the remaining eight forms of dramatic composition belong to the latter. [3]

\section{Vrutti}

Vrutti is the mood or atmosphere created on the stage by a certain dramatic representation. They are four in various: 1 Bhāratī 2 Sāttvathī 3 Ārabhatī and 4 kaisikī. Ārabhatī is the poetic beauty (eg.Sakuntala),Sāttvatī in the emotional mood ( eg.Uttararāmacharita), Ārabhatī the tense atmosphere created by violence (as in Venisamhara or Mudrārāksasa). $\bar{A}$ rabhatī and the Kaisikī have got the artistic atmosphere as in Ratnāvalī. The nātakas and prakaranās should contain all the four vruttis, hence they are pūrnavrutti rūpakas (NS.xvii.7).The other eight rūpakas should be represented without giving prominence to Kaisakī (NS.xviii.8-9).They may contain one of the first three vruttis as the prominent one and the other three to a lesser degree. [4]

\section{Ten Rūpakas}

Nātaka - nātaka is recognized to be the highest type of dramatic composition. It presents historical events and personages. The story has the look of the "possible" or "probably". Its hero ought to be fit in the poetic context and he should belong to the royal dynasty. Bharatamuni says that there should be many rasas in the nātaka and the act should be teeming with Rasa. [5]

Dhananjaya however, accepts the srungāra or the vira as the main sentiment in the Nātaka. Other rasas should be subsidiary. [6] For example see venisamhāra

\section{Prakarana}

The subject - matter of Prakarana is not borrowed from history and idealized but it is a pure creation of dramatist's imagination (fiction).

The hero of a Prakarana is not to be a king nor a divine being but a leader of the community of businessman, a brāhmin, a minister or a high official of the king. He is not to be of exalted character [7] nor is he to be presented to be enjoying luxurious life of a king.

The authors of Nātyadarpana, however, advocate Dhīraprasānta and Dīrodātta also as the hero of the Prakarana. [8]

The heroine in the context of love in Prakarana may be a prostitute or a low - born woman. In other contexts, a high born woman may be heroine. For example see Mrucchakatika of Sudraka for a heroine who in prostitute and the Malatimadhava for a high - born - woman as the heroine.

\section{Samavakāra}

Samavakāra is concerned with the presentation of the events connected with a god. It presents a god as a hero. It eliminates all the details which do not fit in which the life of god. It concerns itself with such events only as are instructive and pleasing. It consists of three acts. Samavakāra is admitted to present srungāra. For example see Samudramanthana of Vatsarāja.

\section{Ihāmruga}

The hero of the Ihāmruga should be a demigod who fights for a heavenly damsel. Its plot presents love that expresses itself in seducing a woman and carrying her away and giving a rub to the opponent. It is a one act play with twelve dramatic persons. The main sentiments are vira and raudra. Kaisikī vṛtti is employed. For example see Rukminīharana of Vatsarāja.

\section{Dima}

The subject matter of Dima has to be historical and well known and the hero also has to be of exalted type as in Nātaka. It has four acts. It presents earthquakes, fall of meteors, eclipse of the sun or the moon, battle etc. It has sixteen dramatist persons including gods, serpent - kings and demons. Sāttvatī and Ārabhatī vruttis are employed in this kind of dramas. Six dramatic sentiments are used here except srungāra, hāsya and sānta.

\section{Vyāyoga}

It is a one-act drama. Its hero is not of exalted nature but a well - known historical person. There are very few female characters in it. It does not have a God, a king or a sage as its hero (divyairdevaih nrupaih riibisca nāyakaih na 


\section{International Journal of Science and Research (IJSR) \\ ISSN (Online): 2319-7064 \\ Index Copernicus Value (2015): 78.96 | Impact Factor (2015): 6.391}

nibaddho'yam). It presents aesthetic configurations with the sentiments of heroism and anger. (vīra and raudra) Examples see Dūtavākya, Dūtaghatotkaca, Madhyamavyāyoga and Urubhanga of Bhāsa.

\section{Anka (Utsrustānka)}

Its subject matter may be well - known. No divine being figures in it. The central fact of which is sorrow (karuna). For example see unmattarāghava of Bhāskara.

\section{Prahasana}

It is of two kinds (i) pure (ii) mixed. A pure prahasana presents the life of a hypocrite of ill repute, who may be a saint, a hermit a householder or Buddhist or Śaiva ascetic. Mixed prahasana according to Bharatamuni, is that in which prostitutes, parasites, paramours and unchaste women appear in their immodest look, dress and moment. Prahasana is so called because it abounds in remarks which excite laughter. Some maintain that pure prahasana is of one act and mixed consists of many. Other maintains that it should be of one act only. Mattavilāsa prahasana of Mahendravikrama is an example for a prahasana.

\section{Bhāna}

Bhāna is not only a one act play but also one - actor play. In it the whole of the subject - matter is presented by one actor using the techniques of akashabashitha or sky-talk. It is full of action and presentation of different states of minds. For example see srungārabhūsanabhāṇa by Vāmanabhatta.

\section{Vìthi}

It may have one or two characters that may belong to any one of the three social levels, high, middle or low. All the sentiments can be used and it is the shortest of the various types of drama. For example see Premābhirāma of Ravipati. The vithi is also a one act piece in rūpakās.

\section{Uparūpakās}

Bharatamuni has not explained this category because of Kohala and his followers had explained precisely at that time. [9]

So the Kohola may be the inventor of these Uparūpakās. Abhinavagupta himself introduced many uparūpakas calling them nrutya - tipes in his commentary of Nātyaśāstra. In the beginning rūpaka plays had only pure acting without songs and dances. Then dramatists wanted to add songs and dances to their plays. As a result of this decision various kinds of Uparūpakās were originated.

The number of Uparūpakās is different according to the Sanskrit dramaturgy and they are as follows.
1. Dvaipāyana

2. Abhinavagupta

3. Dhanika

4. Bhoja

5. Hemachandra

6. Ramachandra and Gunacandra

7. Sāradanaya

8. Sāgaranandin

9. Singabhūpāla

10. Visvanātha

11. Subhankara
(The author of Agnipurana)

(The commentator on Nāṭyasāstra)

(The commentator on Dasarūpaka)

(The author of srungāraprakāsa)

(The author of kāvyānusāsana)

(The authors of Nātyadarpana)

(The author of Bhāvaprakāsa)

(The author of Nātkalaksaṇaratnakosa)

(The author of Rasārnavasudhākara)

(The author of Sāhityadarpana)

(The author of Sangītadāmodara)
$-17$

$-9$

$-7$

$-14$

$-13$

$-15$

$-9$

$-18$
It is to be noted here that among the Uparūpakās very few Uparūpakās are accepted by all the authorities. Nātikā also is not accepted by all Vidyānātha, Sāgaranandin and Dhanika do not mention Nātikā. [10]

Nātikā is regarded by many as Uparūpakās because of it is outside the ten rupaka types enunciated by Bharata.but Bharatha soon after discussing Nataka and Prakaranas makes a special mention of Natikā as a full- fledge stage play(and not as Uparūpaka) and he gives his reason for not considering it as an independent. Rūpaka take the reason is that it is a mixture of Nataka and Prakarana. Therefore, for all practical purpose the natikā is a Rūpaka which occupies the $11^{\text {th }}$ place among the Rūpaka types. It should, therefore, be inserted in to the Rüpaka list.

Here are all the names of Uparūpakās accepted by Indian dramatists.

\begin{tabular}{|l|l|}
\hline 1. Preksaṇa & 16. Ullāpya \\
\hline 2. Karna & 17. Trotaka \\
\hline 3. Dombika & 18. Sattaka \\
\hline 4. Sidgaka & 19. Silpaka \\
\hline 5. Prerana & 20. Durmallikā \\
\hline 6. Bhāṇa & 21. Prasthāna \\
\hline 8. Nartanaka & 22. Bhāṇika \\
\hline 9 Nartanaka & 23. Bhāṇi \\
\hline 10. Rāmakrīdā & 24. Gosthī \\
\hline 11. Rāgakāvya & 25. hallīsaka \\
\hline 1. Saiyāa & 26. Kāvya \\
\hline 2. Sāllāpaka & 27. Srīgadita \\
\hline 3. Pārijāta & 28. Nāttya - Rāsaka \\
\hline 15.Kalpavalli & 29. Rāsaka \\
\hline
\end{tabular}

Volume 6 Issue 1, January 2017 


\section{International Journal of Science and Research (IJSR) \\ ISSN (Online): 2319-7064}

Index Copernicus Value (2015): 78.96 | Impact Factor (2015): 6.391

So, Nātaka which is included in the category of Rūpaka and Nātikā which is represented in Uparūpakās are commonly utilized categories by Sanskrit dramatists. However, critics have argued that there is no difference between the Rūpakās and Uparūpakās. The reason is that in both categories could be seen music and dance.

But Abhinavagupta refuses the above argument and lays down the distinction of Nātaka and Nātikās. When we consider ideas we can assert that those Uparūpakās are based on Nrutta and Nrutya and Rūpakās are based on Nātya. Expressions of bhāva is the predominant element in Uparūpakās[11]

While rasa predominates in Rūpakās in another word, there are three kinds of dramatic forms named Nrutta, Nrutya and Nātya. But the Nrutta (rhythmatic dancing) never seems to have attained the position of a drama. Nrutya was mixed with dance and music combining historical and empirical events. It is connected to Uparūpakās. Nātya is the subtler form of entertainment mixed with four abhinayas, rasa and bhāvas. It is connected to Rūpakas. Nrutya and Nātya are considered as drama but not Nrutta.

\section{The fundamental characteristics of a Sanskrit drama}

1. The means to the end (Arthaprakruti)

Every play aims at certain purpose and there should be graduals steps to reach final goal. Arthaprakrutis are the steps of that gradual process. They are five in numbers.

\section{1) Bïja (The seed)}

Bīja is the means of determining the attitude of the audience. First of all the dramatist has to tell the audience what is going to be presented on the stage. It is simply informative presentation of the drama. For example see Ratnāvalīnātikā. "dīpādanyasmādapi madyādapi jalanidherdisopyantāt ānīya jhatiti ghatayati vidhirabhimatamabhimukhībhūtah [12]

"The fate brings at once the desired object even from a different island, or from the ocean's depths' or from the extreme limit of a quarter, and puts one in possession of that"

It informs the audience of the circumstances, from which the action is to arise. In brief, Bîja is the circumstance leading to the ultimate end which as the plot develops, bears, multifarious results and which is, as it were, the seed of the plot. [13] In other words Bīja is a first clue at beginning of the play as to know the play is going to end. In the Bija of Sakuntala, Dushyanta is blessed with a son of the ascetic and the play gradually develop to culminate and Dushyanta meets his own son.

\section{2) Bindu (The recollection of the motive force)}

It expresses the beginning of the main events. In other words how the hero or heroine can recollect the desired motive in changed circumstance. Further, Bindu is what cements a break in the plot caused by the introduction of some other incident [14]. In the introduction of Ratnāvali nātika the festive scene is meant to introduce all the main characters of the play. A play consists of many conflicts. One conflict has to be resolved to lead to the next conflict. The Bindus are the incidents that serve to solve the conflicts, without which the play cannot move forward.

\section{3) Patāka (Episode)}

Patāka is an episode by which the progress of the plot is illustrated, furthered or hindered. It is of considerable length and sometimes extends to the very end of a play.

\section{4) Prakarī (Episodical incident)}

Prakarī is also an episodically incident of limited duration and minor importance one in which the principal characters take no part.

\section{5) Kārya (The resources)}

Kārya means the set of physical mental and material resources, which the dramatist employs, in the realization of his goal. If he utilized the above mentioned resources for the attainment of the end it is named Kārya.

It is to be noted here that all of these five means to end are not necessary in every drama.

\section{Dramatic situations (Natyāvasthās)}

As regards its development a dramatic plot has five stages or conditions called Avasthās.

They are as follows

"prārambhas ca prayatnasca

tathā prāptesca sambhavah

niyatā ca phalaprāptih

phalayogas ca pancamam [15]

\section{1) Prārambha/Ārambha (beginning or setting on foot of the enterprise)}

The starting point of the story is named Prāmbha. From this point the devolvement of the story will be started. The curiosity of the audience related to the main character will be stored as a seed in their mind. For instance in Abhijnānasākuntala, the treatment of Sakuntalā to the king Duśyantha in the hermitage of kanva sage and attractive behaviors of both can be taken as prārambha. After seen this incident the audience create an idea in their mind about the union of both hero and heroine as lovers. It is a curiosity which is a necessary fact should be in dramas.

\section{2) Prayatna (Effort)}

Prayatna means the starting point of the conflict of the story. In the above mentioned drama the king Dusyantha expressed his love to Sakuntala and he made effort to take her mind. This attempt is called Prayatna.

\section{3) Prāptyāsā/prāptisambhava (Prospect of success)}

It means that the tricks which are used for the benefits of hero or heroine. There are various kinds of obstacles to stop the hero's journey blocking his target. The king Dusyanta had to go back in an unexpected moment and he gave his ring to Sakuntala for remembrance. When the time being she begot a child and she went to meet the king. But he didn't accept her and son as his own due to the effect of sage Durvasa's curse. When she looked at her finger the ring also was lost. If it was there it could be used as a proof. 


\section{International Journal of Science and Research (IJSR) \\ ISSN (Online): 2319-7064}

Index Copernicus Value (2015): 78.96 | Impact Factor (2015): 6.391

\section{4) Niyatāpti (certainty of success)}

Niyatāpti means the certain attainment through the removal of obstacles. In the story of Sakuntala the ring was found with the help of a fisherman. It came to the hand of king and he remembered the Sakuntala's incident.

On that ring the name of the king had been stamped. Then the king decided to accept them as his own wife and son, but he is now unable to trace them.

\section{5) Phalāgama (obtainment of the desired object)}

Phalāyoga or phalāgama means the final approach of the expected destination. The conflict will be resolved at this moment. The fulfillment of the ambitions of the hero or heroine can be seen at this stage. The curiosity will also be resolved. This is the end of the drama. Sakuntala and her son were accepted by the king Dusyanta and the story ends on a happy note. It is to be mentioned here that there are some dramas ending with sad.

\section{Arthopaksepas (intimation scenes)}

There are five kinds of intimation scenes. They are as follows.

1) Pravesaka - Interlude

2) viskambhaka - prelude

3) Ankāvatāra - continuation scene

4) Cūlikā - Offstage sounds and voices

5) Ankamukha- Anticipatory scene

\section{Pravesaka and viskambhaka}

Pravesaka is similar to the viskambhaka. Both explain the events while are not act in the drama but are necessary for the understanding. There incident are the most helpful facts to the progress of play.

In the Nāțasāstra the pravesaka along is mentioned while describing Nātaka: viskambhaka (supporting scene/interlude) is given in the introduction of Prakarna. The pravesaka never came at the beginning of the first act in classical Sanskrit plays. For example pravesaka in Ratnāvali Nātika can be seen between the first and the second act. A Viskambhaka may occur before the first act as in the Mālavikagnimitra and the Ratnāvali. But a Praveśaka can occur only between two acts.

Prof. Karmarkar has mentioned that both Pravesaka and viskambhaka are same and one of them is enough in dramas. But it is to be noted here that there is a difference in between of both categories.

The pravesaka has Prākrit speaking characters only and the Viskambhaka has either Sanskrit speaking middling characters or middling characters or low characters.

\section{Ankamukha \\ When the opening of an act is introduced beforehand by the male or female characters interrupting the subject matter of the previous act is called ankamukha.}

"The an ankamukha or anticipatory scene and the ankāvatāra or continuation scene, on the other hand, are not independent scenes but are pieces dovetailed into acts themselves. The two kinds of scene are quite similar in that they both occur at the close of an act and suggest the beginning of the next, and may, therefore, be called connecting scenes in the proper scenes in the proper sense. Thus, when an ankamukha and ankāvatāra is there , no pravesaka or viskambhaka intervenes between the two acts" [16].

\section{Ankāvatāra}

Ankāvatāra is an ending note of one act and stating note on the other act without breaking its continuity. It relates to the purpose of the germ. The connection between the two acts is named ankāvatāra. It consists in implanting the seed of the subject-matter of an act in the previous act before it has drawn to its close [17].

\section{Cūlikā}

If someone introduces something or somebody staying behind the certain (nepathya) it is called Cūlikā. Actually Cūlikā is the suggestion of some incident from behind the curtain. "A Cūlikā may be employed either at the beginning or in the middle of an act. A Cūlikā of the former type occurs at the beginning of act VII of the Anargharaghava, in which it is intimated by persons behind the scenes that Seetha has entered the fire and walked out unharmed, thus it relates the past act with the present one. In the middle of the second act of the Ratnāvali, offstage persons inform the audience of the pandemonium caused by the monkey that has escaped from its cage.It is a Madhya Cūlikā" [18]

\section{(3) Four abhinayas (representations)}

Abhinaya is the main technique used in Nātya. "abhi” means "towards" and "ni" or "naya" is the root meaning to "carry". Thus as the meaning implies the dancer through the vehicle of Abhinaya has to reach out to the spectators. It is inseparable component of Nātya. Abhinaya is one of the six elements of Nātya. Those six elements are as follows-:
1) Nrutta (pure dance)
2) Geeta (song)
3) Abhinaya (gestures)
4) Tāla (rhythm)
5) Bhāva (emotions)
6) Rasa (sentiment).

There will not be a drama without any abhinayas (representations). Bharatamuni has mentioned it as follows-: vibhāvayati yasmācca - nānārthān hi prayogatah sākhāngopānga sanyuktastasmādabhinayah smrutah [19] He has represented four kinds of abhinaya which are mostly used in dramatic performances. They are as follows-:
1) Vācika abhinaya
2) Āhārya abhinaya
3) Sāttvika abhinaya
4) Āngika abhinaya

\section{Verbal (representation) - (vācika abhinaya)}

Vachika abhinaya is the expression through speech. It is done with the help literature such as poem and dramatics. The Nătyasāstra writes in detail about the different meters in poetry, strong and weak points of poetic writing and diction. It also talks about Figures of speech. Nātyasāstra says that

\section{Volume 6 Issue 1, January 2017




\section{International Journal of Science and Research (IJSR) \\ ISSN (Online): 2319-7064}

Index Copernicus Value (2015): 78.96 | Impact Factor (2015): 6.391

words spoken during nātya should be full of suggested meaning.

In Nātyasāstra, the $15^{\text {th }}$ adhyāya start to explain vocal movements. Up to $19^{\text {th }}$ adyāya it runs with long descriptions. In dramas it is recognized that the vocal movements are the basic features. Bharata muni has said that the vocal movements are the basic features and the body of the dramas. Other movements are depended on vocal movements. There are three kinds of sounds-:

1) Mandra

2) Madhya

3) Tāra

The sound which origins from the heart is called "Mandra" The sound originated from the throat is named "Madhya", "Tāra" means the sound which is originated from the head' These three kinds of sounds are named as "Nāda".

According to Nātyasāstra vācikābhinayas divided into seven parts.

1) Prakāsa-bhāsana - loud speech

2) Ātmagata- bhāsaṇa - self-expressions(self- talk)

3) Apavārita- bhāsaṇa \}asides

4) Janāntika - bhāsaṇa

5) Sāmūhika- bhāsana - group expressions(simultaneous talk)

6) Ekala- bhāsana - single expressions (monologue)

7) Ākāsa- bhāsana - sky expressions (sky-talk)

8) Rahasyakathana - stage-whisper

In Sanskrit dramas we can find all those usages which have used in many places. The languages use by the characters is different according to their classes (Uttama, Madhyama and Nica). Sanskrit is the language which is used by the high class people. Other social groups have used prākrit languages. In Nātyasāstra there is a list of seven prākrit languages.

1) Māgadh̄̄

2) Āvantija

3) Prācayā

4) Saurasen $\overline{1}$

5) Ardha māgadhī

6) Vahlīkā

7) Dakṣinātya

The last one refers many other prākrit languages such as "Apapbranśa" Gujarati, marati and so on. Bharata Muni has explained four kinds of divisions of languages which can be used in Sanskrit dramas.

1) Ati Bhāsā - vedic language

2) Ārya bhāsā - prakrit and other human languages

3) Jāti bhāsā - prakrit and other human languages

4) Yonyantara - the languages of birds and animals

\section{Decoration of body (Āhārya Abhinaya) and stage}

Baratha muni has used the $23^{\text {rd }}$ adyāya to explain Āhārya abhinaya. According to his explanation the aspect of Āhārya abhinaya involves the make- up and costumes, ornaments use of specific colours, hair styles as well as dress code for particular characters. If a dramatist represents a royal character he should use the suitable ornaments and decorations. It is helpful to show the real background of the dramatic events. For instance, in the story of Rama and
Seethā have to use cloths and ornaments related to the kings and queens. Āhārya also includes the stage props and décor. There are four divisions in "Āhārya Abhinaya"

Pusta (Models)

1) Alankāra prasādhana

2) Angaracanā

3) Sanjeeva

"Pusta" means symbolized features which are used on the stages. Such as rocks vehicles trees, mountains and animals. In the second division explains bodily (physical) decorations such as garlands, ornaments and costumes. There should be a consideration about the male and female characters. The third one explains the decoration of the body which is done using the paints. Mostly four colours are used in this section. Those four colours are white, yellow, blue and red. They are used according to the characters and natural objects. Gods, kings, gandharvas, yakșās are decorated with brown colours. This colour is prepared by mixing above mentioned colours. The rocks, oceans, stars and rivers are decorated with white colours.

In the dramas the forms of the various beings are used creating the natural back grounds and environment. Those beings are divided into three parts.

1) Serpents

2) Birds and Human beings

3) Animals (such as horses, deers and elephants)

If the dramatist uses these forms, the drama becomes a natural and a live show.

So, the costumes and physical decorations of the actors and the theatre are called Āhārya abhinaya.

In brief, Abhinaya is the art of communicating bhāva (emotion) to produce rasa (aesthetic enjoyment).The rasa theory of the Nātyasāstra is considered one of its most important contributions, with several scholars over the centuries until today analyzing it extensively. The famous rasa sutra or basic "formula" to invoke rasa, as stated in the Nātyasāstra, is as follows-:

"vibhāva anubhāva vyabbhicāri samyogāt rasa nispattih"

Vibhāva determines causes bhāva while anubhāva is the physical result or the performance of the bhāva that is communicated through the abhinaya. The most important vibhāva and anubhāva are those that invoke the sthāyi bhāva,or the principle emotion at the moment. Thus, the rasa sutra states that the vibhāva, anubhāva, and vyabhicāri bhāvas together produce rasa

Sātvika abhinaya (Depiction of mental state of mind/facial expressions)

The word satva means mind. If someone shows feelings which are originated in the mind using his external organs, it is called Sātvika abhinaya. On the other hand, it can be said Sātvika abhinaya is mental message, emotions or image communicated to the spectators with sense organs. The dancer or actor has to bring their own experiences to create feelings of the audience. Actually this kind of Abhinaya can be interpreted as one that is real and natural. They are very subtle feelings that we experience (like horripilation, perspiration or tears etc).It can be expressed only if it is 


\section{International Journal of Science and Research (IJSR) \\ ISSN (Online): 2319-7064}

Index Copernicus Value (2015): 78.96 | Impact Factor (2015): 6.391

really heart felt. Sātvika abhinaya are the feelings created in the mind that are extremely projected by Āngika and Vācika. This abhinaya is also called as psycho-physical representation.

There are eight sātvika Abhinayas.

1) sthambha - motionless

2) sweda - perspiration

3) romanca - horripilation (it is experienced when the mind is excited and hair on the body stand erect)

4) asru - tears

5) vepathu - shivering

6) pralaya - faint out of shock

7) vaivarnya - change of skin complexion like to be red in anger.

8) svarabhanga - change in the voice tone due to over emotions.

The different kinds of Sātvika abhinaya related to male female actors. Here are the three facts related to female characters.

1) Angaja

2) Svabhāvika

3) Ayatnaja

And also there are 8 facts related to the male actors. They are as follows-:

1) Sobhā

2) Vilāsa

3) Mādhurya

4) Sthairya

5) Gambhīrya

6) Lalita

7) Audārya

8) Teja

\section{Āngika abhinaya (Bodily gestures/movement of the body)}

This relates to the movement of the body, and how the thing to be expressed is portrayed by movement of the anga or limbs, which include facial expressions. There are two types of basic abhinayas as padārtha abhinaya (when the artist delineates each word of the lyrics with gestures and expressions), or vākyārtha abhinaya (where the dancer acts out an entire stanza or sentence). Āngika abhinaya uses the total body to express certain meaning. Hasta (hand) Abhinaya is an important aspect of Āngika. Here, body is divided into three major parts - the anga, pratyanga and upānga.

1) The six angās -: Siras (head),Hasta (hand),Vaksas (chest),Pārsva (sides),Katitata (hips),Pāda (leg). Some consider Grivā (neck) to be the seventh.

2) The six pratyangās -: Skandha (shoulders),Bāhu (arms),Prusta (back),Udara (stomatch),Uru (calves),Janghā (shanks).Some consider Manibandha (wrist),Kurpara (elbows) and Jānu (knees) also as pratyanga.

3) The twelve Upāngās or minor parts of the head or face which are important for facial expression.-: Druști (eyes),Bhrū (eye-brows),Puta (pupil),Kapola (cheek),Nāsikā (jaws),lips,teeth,tongue,chin and face.
4) In the fourth chapter of Nātyasāstra can be learnt 108 karanas and 32 angas which are represented using the legs and hands in dramas. And also various kinds of angas,upāngas and pratyangas are explained in 8,9 and 10 adhyāyas. $11^{\text {th }}$ and $12^{\text {th }}$ adhyāyas are used for the explanatory notes on footsteps (cārī and mandala etc).So also in the $24^{\text {th }}$ and $26^{\text {th }}$ adhyāyas can be seen citrābhinayas which are used for the production of natural sceneries in the dramas. All these facts are specially represented for the Āngika abhinaya.

\section{Bhāvas (emotions)}

The Nātyasāstra divides the bhāva into three categories:

1.sthāyi bhāva-the principle emotion

2.vyabhicāri or sancāri bhāva, the transient emotions; and 3.sātvika bhāva-the involuntary emotion.

There are eight stāyi bhavās while there are 33 vyabhicāri bhāvās. They are used to reinforce the sthāyi. Moreover, there are eight sātvika bhāvas,which are the involuntary reactions manifested in the body, such as the falling of tears or temporary paralysis, when one invokes successfully the sthāyi in the deepest manner possible, i.e., when the sātvika abhinaya is invoked.

The sātvika bhāvas as explained in sātvika abhinaya themselves are represented in Nātyasāstra as follows-: "sthambah svedotha romancah-svarabhedo'tha vepathuh Vaivarnyam asrupralaya-ityastau sātvikāh smrutah [20] (22) These facts are explained by Bharatamuni and Dhanika as follows-:

"satvam nāma mana prabhavam.etadeva samāhitanmanastvādutpadyate iti bharatah.etadevasya satvam yat duhkhitena praharsitena vā asru romanchadayo nivartyante.tena satvena nirvruttā bhāvāh.sātvikāh kāh bhāvāh.tadbhāva bhāvanam ca bhāvah-iti dhanikah.pruthag bhāvā bhavantyannyenubhavatvepi sātvikāh.satvādeva samutpattestastacca tadbhāva bhāvanam iti dhanikah". [21]

Thus, physical expression of the feelings of the mind is called sātvika.

For example, If the principle emotion or sthāyi bhāva is anger (krodha).Let us say the cause of anger, vibhava, is betrayal by a friend. The anger will be more potent if the vibhāva is strongly established. If the sthāyibhāva is deeply felt, then it will result in the physical manifestation of anger such as burning eyes and heaving chest, which is the anubhava. But in anger, one can make fun of and laugh sarcastically at the object of one's anger. One can feel sorrow when thinking of the happy times spent together earlier. One can feel disgust for the other person's behavior or be amazed at the change in him now. Through all this, the fundamental thread of anger must be maintained. But the transient emotions-the vyabhicāri bhāvas of laughter, sorrow, disgust and amazement - enhance the present angry state. If performed with appropriate āngika, vācika, ahārya and above all, true sātvika abhinaya, it will invoke the rasa of raudra or anger in the spectator whose mind is completely in accordance with the performer.

\section{Rasa}

Volume 6 Issue 1, January 2017 


\section{International Journal of Science and Research (IJSR) \\ ISSN (Online): 2319-7064 \\ Index Copernicus Value (2015): 78.96 | Impact Factor (2015): 6.391}

The Nātyasāstra states that the goal of any art form is to invoke rasa. Rasa, which literally means taste, can be loosely translated as aesthetic appreciation or enjoyment of an art. "The rasa is that aesthetic and impersonal joy that the spectator inspired and moved by the clever acting of the actor who is assisted by external aids is expected to realize in his mind" [22] The word rasa is derived from the root "ras" (to relish,taste) and means "something that has to be relished or enjoyed'. In drama this relishing is possible through mental perception alone. [23] However, that is a superficial definition that does not do justice to the spiritual and philosophical implications of this term. When at a given moment no other reality exists but that of the art, when the spectator and the artist have become one in spirit, then one experience fully the rasa.

The Nāṭasāstra lists eight rasas but scholars in later centuries added a ninth one (Sānta rasa) to create the concept of the navarasas or the nine rasas.

In Nātyasāstra it is listed thus-:

"srungāra hāsya karuna -raudra vīra bhayānakah

Bibhatsādbhuta sangjñaucetyastau nātye rasāh smrutāh” [24]

\section{(4) Two practices}

There are two kinds of principle divisions in dramas as assumed by all the dramatics. They are-:

1) Nātyadharmī - conventional practice

2) Lokadharmī - realistic practice

The former is poetic and stylistic in nature, following a codified manner of presenting emotion and expression which pertains to the conventions of the stage, which appear to have greater 'artistry' by virtue of taking something from natural life and rendering it in a suitably stylized way. The dramas which are represented with the various kinds of dramatic features such as abhinayas, synthetic creations and events are named Nātyadharmī. [25] Lokadharmī is the opposite: realistic and un-stylized, involving very natural expression and movement, as occurs in daily life. Often this is the more difficult as the possibilities for interpretation of an emotion or a line of poetry are endless. In the $13^{\text {th }}$ chapter of Nātyasāstra the concept of Lokadharmi has defined with enough details. According to those explanations there is no usage of abhinayas in that category but it is full of natural actions and events.

\section{References}

[1] Sanskrit Nāṭikas, Parvati Tandon, P. 1, 1986, Munshiram Manoharlal Publishers, New Delhi

[2] "avasthānukrutir nātayam - rūpam drusyatayopyate, rūpakam tatsamāropāt”. - Dasarūpaka I. 7, Dhananjaya, with the Commentery of Dhanika, Varanasi, 1962

[3] “evam nātakaprakaraṇābhyām pūrṇa vruttivrutyangābhyām vruttinyūnām ca rūpakabhedānām parikalpanam”. The author of Dasarūpaka classifies ten forms of drama according to subject matter, hero and sentiment. "Vastu, neta rasah tesām bhedakah" - Dasarūpaka, I. 16

[4] See, The Sanskrit theater and stagecraft, Prof. Walter Marasinghe,pp.395-421.

[5] Nāṭayasāstra, (KSS, xx, 12 - 14)
[6] "eko raso'nḡ̄ kartavyo - vīra srungāra evavā, angamanye rasāh sarve" - kuryānnirvahanedbhutam Dasarūpaka,3.33 Bhavabhūtī's uttararāma carita presents karuna as an Angi - rasa.

[7] Nātyaśāstra (KSS), xx, 49 - 59)

[8] "Dhīrodattadhīra prasānto prakarane"Nātyadarpana,p.117,Ramacandra and Gunacandra,vol.I.Baroda"1929

[9] "sesamuttaratantrena

kohalastu karisyati....kohalādibirevam tu vatsa sāndilya dhūrtibhih” - Nāṭyasāstra, IV, Gaekwad's oriental series, Baroda, 1958, XXXVII, 18 - 24)

[10] Sanskrit nātikas, Parvati Tondon, p. 16

[11] Theory of Rasa in Sanskrit drama by H. R. Mishra, P. 193, Bhopal, 1966

[12] Ratnāvali, edited by M. R. Kale, P. 7, Motilal Banarasidass, Delhi

[13] Ratnāvalī, edited by M. R. Kale, introduction p. ii, Motilal Banarasidass, Delhi

[14] "avāntarārtha vicchede binduracchedakāranam"

[15] Nātya Sāstra, 21 adhyāya, verse 9

[16] See The Sanskrit theater and stagecraft, Prof. Walter Marasinghe,pp.347f.

[17]For description of Ankāvatāra and Ankamukha and examples, see The Sanskrit theater and stagecraft, Prof. Walter Marasinghe,pp.347f

[18] See The Sanskrit theater and stagecraft, Prof. Walter Marasinghe, pp.347f.

[19] N.S.adhyāya 8,verse 7

[20] N.S Batuka Nātha sharma's edition,Chowkhamba.2005, VI.22 verse.

[21]N.S, Batuka Nātha sharma's edition,Chowkhamba.2005, VII. P.95

[22] The Sanskrit theater and stagecraft, Prof. Walter Marasinghe, p 185.

[23] “na rasanāvyāpāra āsvādanam,api tu mānasa eva” N.S ,VI.33 verse.

[24] N.S.6, 15 verse.Batuka Nātha sharma’s edition,Chowkhamba.2005

[25] N.S.14, 71-79 verses.Batuka Nātha sharma's edition,Chowkhamba.2005 